\title{
Clinical Features of COVID-19 on Patients With Neuromyelitis Optica Spectrum Disorders
}

Samira Luisa Apostolos-Pereira, MD, PhD, * Lis Campos Ferreira, MD, * Mateus Boaventura, MD, * Nise Alessandra de Carvalho Sousa, MD, Gabriela Joca Martins, MD, José Arthur d'Almeida, MD, PhD, Milena Pitombeira, MD, Lucas Silvestre Mendes, MD, Thiago Fukuda, MD, Hideraldo Luíz Souza Cabeça, MD, PhD, Luciano Chaves Rocha, MD, Bianca Santos de Oliveira, MD, Carla Renata Vieira Stella, MD, Enedina Maria Lobato de Oliveira, MD, PhD, Leizian de Souza Amorim, MD, Andréa Ferrari de Castro, MD, Antonio Pereira Gomes Neto, MD, Guilherme Diogo Silva, MD,

Lucas Bueno, MD, Maria de Morais Machado, MD, Rafael Castello Dias-Carneiro, MD, MS,

Ronaldo Maciel Dias, MD, Alvaro Porto Moreira, MD, Ana Piccolo, MD, Anderson Kuntz Grzesiuk, MD, Andre Muniz, MD, Caio Diniz Disserol, MD, Claudia Ferreira Vasconcelos, MD, PhD,

Damacio Kaimen-Maciel, MD, Denise Sisterolli Diniz, MD, PhD, Elizabeth Comini-Frota, MD, PhD,

Fernando Coronetti Rocha, MD, PhD, Gutemberg Augusto Cruz dos Santos, MD,

Yara Dadalti Fragoso, MD, PhD, Guilherme Sciascia do Olival, MD, Heloisa Helena Ruocco, MD, PhD, Heloise Helena Siqueira, MD, Henry Koity Sato, MD, José Alexandre Figueiredo, Jr., MD, Leandro Cortoni Calia, MD, Mario Emilio Teixeira Dourado, Jr., MD, Letícia Scolari, MD, Herval Ribeiro Soares Neto, MD, Luiz Melges, MD, Marcus Vinicius Magno Gonçalves, MD, PhD, Maria Lucia Vellutini Pimentel, MD, PhD, Marlise de Castro Ribeiro, MD, Omar Gurrola Arambula, MD, Paulo Diniz da Gama, MD, PhD, Renata Leite Menon, MD, Rodrigo Barbosa Thomaz, MD, Rogério de Rizo Morales, MD, PhD, Silvana Sobreira, MD, Suzana Nunes Machado, MD, PhD, Taysa Gonsalves Jubé Ribeiro, MD, Valéria Coelho Santa Rita Pereira, MD, Vanessa Maia Costa, MD, Adaucto Wanderley da Nóbrega Junior, MD, Soniza Vieira Alves-Leon, MD, PhD,

Marilia Mamprim de Morais Perin, MD, Eduardo Donadi, PhD, Tarso Adoni, MD, PhD, FAAN, Sidney Gomes, MD, Maria Brito Ferreira, MD, PhD, Dagoberto Callegaro, MD, PhD, Maria Fernanda Mendes, MD, PhD, Doralina Brum, MD, PhD, and Felipe von Glehn, MD, PhD, FAAN, and the Neuroimmunology Brazilian Study Group

Neurol Neuroimmunol Neuroinflamm 2021;8:e1060. doi:10.1212/NXI.0000000000001060

\section{Abstract}

\section{Background and Objectives}

To describe the clinical features and disease outcomes of coronavirus disease 2019 (COVID19 ) in patients with neuromyelitis optica spectrum disorder (NMOSD).

\section{Methods}

The Neuroimmunology Brazilian Study Group has set up the report of severe acute respiratory syndrome (SARS-CoV2) cases in patients with NMOSD (pwNMOSD) using a designed webbased case report form. All neuroimmunology outpatient centers and individual neurologists were invited to register their patients across the country. Data collected between March 19 and July 25, 2020, were uploaded at the REDONE.br platform. Inclusion criteria were as follows:

\author{
Correspondence \\ Dr. von Glehn \\ felipeglehn@gmail.com
}

MORE ONLINE

COVID-19 Resources

For the latest articles, invited commentaries, and blogs from physicians around the world NPub.org/COVID19

\footnotetext{
*These authors contributed equally to this work.

From the Hospital das Clínicas (S.L.A., M.B., G.D.S., L.B., C.C.D.D., D.C.), FM-USP, São Paulo; Universidade Federal de Sergipe and Univ. Tiradentes (L.C.F.), Aracaju; Hospital Univ. Getúlio Vargas (N.A.d.C.S.), Manaus; Hospital Geral de Fortaleza (G.J.M., J.A.d.A., M.S.P., L.S.M.); Universidade Federal da Bahia/Ebserh (T.F.), Salvador; Hospital Ophir Loyola (H.L.S., L.C.R.), Belém; FUNAD (B.E.S.), João Pessoa; UNICAMP (C.R.A.), Campinas; Universidade Federal de São Paulo (E.M.L., L.d.S.A.), UNIFESP; Universidade Metropolitana de Santos (A.A.F.d.C., Y.D.F.); Santa Casa (A.P.G.), Belo Horizonte; Hospital da Restauração (M.I.d.M., A.J.P.), Recife; Santa Casa (R.P.C., M.F.M.), São Paulo; Hospital de Base do Distrito Federal (R.M.D.), Brasília; Hospital Santa Marcelina (A.C.P.), São Paulo; Private Service (A.K.), Cuiabá; Clínica AMO (A.M.), Salvador; Hospital Universitário Gaffree e Guinle (C.C.F.V.), Rio de Janeiro; Santa Casa (D.R.K.M.), Londrina; Universidade Federal de Goiás (D.S.D.), Goiânia; Private Service (E.R.C.-F.), Belo Horizonte; Faculdade de Medicina de Botucatu (F.C.G.D.R, D.G.B.), UNESP; Santa Casa and ABEM-Assoc. Brasileira de Esclerose Múltipla (G.S.d.O.), São Paulo; Universidade Estácio de Sá and Universidade Federal Fluminenses (G.A.C.), Rio de Janeiro; Universidade Federal Fluminense (H.H.R.), Campinas; Universidade Federal do Mato Grosso (H.H.S., J.A.F., L.S.), Cuiabá; Private Service (H.K.S.), Curitiba; IAMSPE (H.R.S.N.), São Paulo; Private Service (L.C.C.), São Paulo; Faculdade de Medicina de Marília (L.D.M.); Univ. da Região de Joinville (Univille) (M.V.M.G.); Santa Casa (M.L.V.P.), Rio de Janeiro; Univ. Federal R G Norte (M.E.T.D.), Natal; Univ. Federal Ciências da Saúde de Porto Alegre (M.d.C.R.); PUC (P.D.d.G.), Sorocaba; Hospital Israelita Albert Einstein (R.B.T.), São Paulo; Univ. Federal de Uberlândia (R.d.R.M.); Hospital Beneficência Portuguesa (S.G.), São Paulo; Hospital Memorial São José (S.S.), rede D’OR, Recife; Univ. Federal do Rio de Janeiro (S.N.M., V.C.S.R.P.); Private Service (S.N.M.), Florianópolis; Univ. Federal de Goiás (T.A.G.J.R.), Goiânia; Hospital Neurológico de Goiânia (V.M.C.); Pontifícia Universidade Católica de Campinas (M.M.d.M.P.); Hospital Universitário da Universidade Federal de Santa Catarina (A.W.d.N.J.), Florianópolis; Faculdade de Medicina de Ribeirão Preto (E.A.D.), USP; Hospital Sírio-Libanês (T.A.), São Paulo; and Faculty of Medicine (F.v.G.), University of Brasilia, Brazil.
}

Go to Neurology.org/NN for full disclosures. Funding information is provided at the end of the article.

The Article Processing Charge was funded by Brazilian Academy of Neurology.

This is an open access article distributed under the terms of the Creative Commons Attribution-NonCommercial-NoDerivatives License 4.0 (CC BY-NC-ND), which permits downloading and sharing the work provided it is properly cited. The work cannot be changed in any way or used commercially without permission from the journal. 


\section{Glossary}

AQP4 = aquaporin 4; CBA = cell-based assay; CI = confidence interval; COVID-19 = coronavirus disease 2019; DMT = disease-modifying therapy; MS = multiple sclerosis; NMOSD = neuromyelitis optica spectrum disorders; OR = odds ratio; pwNMOSD = patients with NMOSD; RT-PCR = reverse transcription-polymerase chain reaction; SARS = severe acute respiratory syndrome.

(1) NMOSD diagnosis according to the 2015 International Panel Criteria and (2) confirmed SARS-CoV2 infection (reverse transcription-polymerase chain reaction or serology) or clinical suspicion of COVID-19, diagnosed according to Center for Disease Control / Council of State and Territorial Epidemiologists (CDC/CSTE) case definition. Demographic and NMOSDrelated clinical data, comorbidities, disease-modifying therapy (DMT), COVID-19 clinical features, and severity were described.

\section{Results}

Among the 2,061 pwNMOSD followed up by Brazilian neurologists involved on the registry of COVID-19 in pwNMOSD at the REDONE.br platform, 34 patients (29 women) aged 37 years (range 8-77), with disease onset at 31 years (range 4-69) and disease duration of 6 years (range 0.2-20.5), developed COVID-19 (18 confirmed and 16 probable cases). Most patients exhibited mild disease, being treated at home (77\%); 4 patients required admission at intensive care units (severe cases); and 1 patient died. Five of 34 (15\%) presented neurologic manifestations (relapse or pseudoexacerbation) during or after SARS-CoV2 infection.

\section{Discussion}

Most NMOSD patients with COVID-19 presented mild disease forms. However, pwNMOSD had much higher odds of hospitalization and intensive care unit admission comparing with the general Brazilian population. The frequency of death was not clearly different. NMOSD disability, DMT type, and comorbidities were not associated with COVID-19 outcome. SARS$\mathrm{CoV} 2$ infection was demonstrated as a risk factor for NMOSD relapses. Collaborative studies using shared NMOSD data are needed to suitably define factors related to COVID-19 severity and neurologic manifestations.

Coronavirus disease 2019 (COVID-19), as an unprecedented challenge to global public health, requires international data collection to address the effect of the disease in groups at potential increased risk. ${ }^{1}$ Brazil, one of the main epicenters of the COVID-19 pandemic, reached the unfortunate milestone of more than 2 million severe acute respiratory syndrome (SARS-CoV2) infection cases and more than 100k deaths (accessed on August 8, Johns Hopkins COVID19 resource center). The international community has rapidly launched several patient registries to ascertain the overall effect of the COVID-19 in neuroimmunologic diseases, particularly multiple sclerosis (MS). ${ }^{2}$ Notwithstanding, some series of MS patients have been recently reported. ${ }^{3-6}$ Scarce data are available about the effect of SARS-CoV2 infection on patients with neuromyelitis optica spectrum disorders (NMOSD), a severe CNS autoimmune astrocytopathy treated with immunosuppressant therapy. ${ }^{7,8}$

Compared with MS, patients with NMOSD (pwNMOSD) are older at disease onset and present higher disability, higher rate of hospitalization, and early-age risk of mortality. ${ }^{8} \mathrm{Be}$ cause NMOSD prognosis is relapse-related, it is mandatory to start disease-modifying therapy (DMT) soon after the index clinical event. ${ }^{9}$ Many of the commonly used DMTs for NMOSD are cell-depleting immunosuppressants, which may potentially increase the risk of viral and bacterial infections. ${ }^{10}$ The effect of SARS-CoV2 infection on pwNMOSD is a gap of knowledge. The purpose of this study was to describe the frequency and clinical features of COVID-19 in a cohort of patients with NMOSD.

\section{Methods}

\section{Study Design and Participants}

This was a prospective observational cohort study developed by the Brazilian Academy of Neurology using the REDONE.br (Brazilian Registry of Neurological Diseases) platform, starting on March 19, 2020, and punctually closed on July 25, 2020, to be resumed afterward. REDONE.br invited 51 neuroimmunology university and private centers distributed across all 27 Brazilian states. Forty-seven of 51 centers (92\%) from 19 states $(70 \%)$ participated in this study. Each referral center received a link to register all flu-like symptoms among pwNMOSD using a web-based case report form. Neurologists have continuously updated the REDONE.br database reporting the longitudinal follow-up of patients during the SARSCoV-2 pandemic. Inclusion criteria: (1) patients diagnosed according to the 2015 International Panel for NMOSD criteria $^{10}$ and (2) flu-like illness presenting a SARS-CoV2 positive test classified as a confirmed case (reverse transcriptionpolymerase chain reaction [RT-PCR] and/or IgA/IgM or IgG seropositivity), or clinical suspicion of COVID-19 diagnosed according to CDC/CSTE case definition, ${ }^{9}$ classified as a possible case. The cell-based assay (CBA) test to detect antibodies against aquaporin 4 (AQP4-IgG) was performed in most 
patients. Exclusion criteria for this study included confirmed infections by H1N1, H3N2, or influenza B and myelin oligodendrocyte protein (MOG)-IgG seropositivity. The anti-MOG IgG was detected using an in-house CBA in live human embryonic kidney (HEK)-293 cells as described elsewhere. ${ }^{11}$

\section{Standard Protocol Approvals, Registrations, and Patient Consents}

This study was approved by the Ethics Committee of the "Faculdade de Medicina de Botucatu, Universidade Estadual Paulista (Unesp)" under the internal review board number CAAE 31021220.2.0000.5411. All participants signed a written informed consent form before enrollment. This study was conducted according to the latest Declaration of Helsinki.

\section{NMOSD Characteristics}

Data collection was related to specific variables such as sex, comorbidities, age at disease onset, disease duration, disability at the last follow-up evaluated by Expanded Disability Status Scale (EDSS), previous use of DMT, maintenance or not during the pandemic, and relapse after infection.

\section{COVID-19 Features}

Data regarding COVID-19 included diagnostic criteria (confirmed or probable) and clinical presentation. Chest CT data were recorded when available.

\section{Clinical Outcome}

Clinical outcome and disease severity of COVID-19 were evaluated in the pwNMOSD considering the variables: treatment at home (mild cases) or at hospital (moderate cases) and the development of critical conditions (severe cases), such as sepsis, septic shock, acute respiratory syndrome, and need of ventilatory support. In addition, demographic and clinical features of COVID-19 in pwNMOSD were compared with those reported for the general Brazilian population, using similar features as observed for patients with NMOSD (home treatment, hospital admission, intensive care unit [ICU] admission, death, sex, age range [15-59 years], and comorbidity). Data from the Brazilian population were obtained at official national sources at antigo.saude.gov.br/images/pdf/2020/July/ 30/Boletim-epidemiologico-COVID-24.pdf and opendatasus. saude.gov.br/dataset/bd-srag-2020. ${ }^{12}$ Data collection from both groups started from the beginning of the pandemics in Brazil till the closure date of this study (July 25, 2020). For both groups, we considered patients who exhibited positive results for SARS-CoV2 by RT-PCR or serology (as defined by the Brazilian Ministry of Health) from the beginning of the pandemics in Brazil till the closure date of this study (July 25, 2020).

\section{Statistical Analysis}

Demographic data, NMOSD clinical and disability profile, COVID-19 clinical features, and outcome were descriptively reported. The comparison of means between groups' home treatment and hospital admission was made using the Student $t$ test. The comparison of the proportions between groups for the categorized variables was performed by the test of difference of proportions, analogous to the $\chi^{2}$ test. The odds ratio (OR) and the $95 \%$ confidence interval $(95 \% \mathrm{CI}$ ) were obtained through the contingency table of the association between groups and the categorized variables of interest. In addition, the clinical outcome of COVID-19 in patients with NMOSD was compared with the Brazilian general population, using the 2-tailed Fisher's exact test, estimating the OR and the $95 \% \mathrm{CI}$. Considering the exploratory nature of the study, no adjustment for multiple comparison was made, and $p$ values $\leq 0.05$ were significant. All analyzes were performed using the SAS for the Windows v9.4 program.

\section{Data Availability}

Anonymized patient data are available on request.

\section{Results}

A total of 34 cases of SARS-CoV2 infection, classified as confirmed $(n=18)$ or probable $(n=16)$, were identified in a cohort of 2,061 pwNMOSD, distributed among all 5 Brazilian regions (north $=82$ patients, northeast $=643$, midwest $=140$, southeast $=1,119$, and south $=77$ ). Most COVID-19 probable or confirmed cases were from the southeast region $(\mathrm{n}=$ $15 ; 44 \%)$, followed by northeast $(\mathrm{n}=13 ; 38 \%)$ and north $(\mathrm{n}=$ 6; 18\%) regions.

Demographic, clinical, and laboratory features of NMOSD patients exhibiting COVID-19 are summarized in Table 1. The women:men ratio was of $6: 1$. The mean age was 37 years old (range 8-77), and only 3 of 34 patients were older than 50. The mean age at NMOSD diagnosis was 31 years (range 4-69), and disease duration was 6 years (range 0.2-20.5). The median EDSS was 3.5, ranging from 0 to 8.5. Fifteen of 27 patients (56\%) exhibited AQP4-IgG, 12 patients did not exhibit anti-AQP4 IgG, and 7 patients were not tested; however, all patients fulfilled the 2015 International Panel Criteria.

More than half of patients (56\%) had no comorbidity, whereas $24 \%$ of patients exhibited more than 1 comorbidity. Hypertension (21\%), obesity (24\%), diabetes (15\%), and dyslipidemia (15\%) were the most common comorbidities. Nine patients presented lymphopenia, which was severe in 2 patients $\left(364\right.$ and $600 / \mathrm{mm}^{3}$ ), and none of these patients needed to be hospitalized for COVID-19 treatment.

General COVID-19 characteristics in pwNMOSD are listed in Table 2. Main symptoms included fever or chill (79\%), dry cough (56\%), myalgia (65\%), fatigue (53\%), coryza (47\%), and dyspnea (38\%). Gastrointestinal symptoms that occurred in 7 of 34 patients are diarrhea $(7 ; 21 \%)$ and abdominal pain (3; $9 \%)$. Neurologic symptoms included headache (62\%), anosmia (50\%), ageusia (24\%), and delirium (3\%). Most patients (77\%) exhibited mild COVID-19 forms being treated at home, and 8 patients (23\%) needed to be hospitalized (moderate and severe cases). No differences were observed 
Table 1 Demographic, Clinical, and Treatment Features of Patients With Neuromyelitis Optica Spectrum Disorders Who Developed COVID-19

\begin{tabular}{|c|c|c|c|c|}
\hline & $\begin{array}{l}\text { Total } \\
(n=34)\end{array}$ & $\begin{array}{l}\text { Home } \\
\text { treatment } \\
(n=26)\end{array}$ & $\begin{array}{l}\text { Hospital } \\
\text { admission } \\
(n=8)\end{array}$ & $\begin{array}{l}p \text { Value or } \\
(95 \% \mathrm{CI})\end{array}$ \\
\hline Age (mean, range) & $37(8-77)$ & $42(8-56)$ & $36(16-77)$ & 0.72 \\
\hline Age of NMOSD onset (mean, range) & $31(4-69)$ & $35(4-54)$ & $31(14-69)$ & 0.89 \\
\hline Disease duration-y (mean, range) & $6(0.2-20.5)$ & $6(0.2-20.5)$ & $5(2-8.5)$ & 0.41 \\
\hline EDSS (median, range) & $3.5(0-8.5)$ & $3(0-8.5)$ & $4(1-8.5)$ & 0.25 \\
\hline \multicolumn{5}{|l|}{$\operatorname{Sex}(n, \%)$} \\
\hline Female & $29(85)$ & $22(85)$ & $7(87.5)$ & $0.84 ; 0.8(0.1-8.2)$ \\
\hline Male & $5(15)$ & $4(15)$ & $1(12.5)$ & \\
\hline \multicolumn{5}{|l|}{ Color (n, \%) } \\
\hline White & $9(27)$ & $6(23)$ & $3(37)$ & $0.73 ; 0.5(0.1-2.7)$ \\
\hline African descent & $23(67)$ & $19(73)$ & $4(50)$ & $0.43 ; 2.7(0.5-13.9)$ \\
\hline Asian descent & $1(3)$ & $1(4)$ & 0 & 1.00 \\
\hline Not informed & $1(3)$ & 0 & $1(13)$ & 1.00 \\
\hline \multicolumn{5}{|l|}{ No. of comorbidities (n, \%) } \\
\hline No comorbidities & $19(56)$ & $15(58)$ & $4(50)$ & $1.00 ; 1.4(0.3-6.7)$ \\
\hline 1 comorbidity & $7(21)$ & $5(19)$ & $2(25)$ & $1.00 ; 0.71(0.1-4.7)$ \\
\hline$>1$ comorbidity & $8(23)$ & $6(23)$ & $2(25)$ & $1.00 ; 0.9(0.1-5.7)$ \\
\hline \multicolumn{5}{|l|}{ Comorbidities (n, \%) } \\
\hline Obesity & $8(24)$ & $6(23)$ & $2(25)$ & $1.00 ; 0.9(0.1-5.7)$ \\
\hline Hypertension & $7(21)$ & $5(19)$ & $2(25)$ & $1.00 ; 0.7(0.1-4.7)$ \\
\hline Diabetes & $5(15)$ & $3(12)$ & $2(25)$ & $0.71 ; 0.4(0.1-2.9)$ \\
\hline Dyslipidemia & $5(15)$ & $2(8)$ & $3(38)$ & $0.13 ; 0.1(0.02-1.1)$ \\
\hline Cardiomyopathy & $1(3)$ & 0 & $1(13)$ & 1.00 \\
\hline Neoplasm & $1(3)$ & $1(4)$ & 0 & 1.00 \\
\hline Other autoimmune disease & $3(9)$ & $3(12)$ & 0 & 0.77 \\
\hline Smoking & $1(3)$ & $1(4)$ & 0 & 1.00 \\
\hline \multicolumn{5}{|l|}{ Treatment $(\mathrm{n}, \%)$} \\
\hline No treatment & $2(6)$ & $1(4)$ & $1(13)$ & $0.96 ; 0.3(0.02-5.1)$ \\
\hline AZT & $10(30)$ & $9(35)$ & $1(13)$ & $0.45 ; 3.7(0.3-35)$ \\
\hline MTX & $1(3)$ & $1(4)$ & 0 & 1.00 \\
\hline MMF + PD & $1(3)$ & 0 & $1(13)$ & 1.00 \\
\hline RTX & $12(35)$ & $9(35)$ & $3(38)$ & $1.00 ; 0.9(0.2-4.6)$ \\
\hline$A Z T+R T X$ & $1(3)$ & 0 & $1(13)$ & 1.00 \\
\hline$A Z T+P D$ & $5(15)$ & $4(15)$ & $1(13)$ & $1.00 ; 0.9(0.1-10)$ \\
\hline$R T X+P D$ & $2(6)$ & $2(8)$ & 0 & 1.00 \\
\hline
\end{tabular}

Abbreviations: $A D=$ autoimmune disease; $A Z T$ = azathioprine; $\mathrm{Cl}=$ confidence interval; $\mathrm{MTX}=$ methotrexate; $\mathrm{MMF}=$ mycophenolate $\mathrm{mofetil} ; \mathrm{NMOSD}=$ neuromyelitis optica spectrum disorders; $\mathrm{PD}=$ prednisone; RTX = rituximab. 
Table 2 Clinical and Neurologic Features, and Outcome of COVID-19 in Patients With Neuromyelitis Optica Spectrum Disorders (NMOSD), Encompassing Confirmed $(n=18)$ and Probable $(n=16)$ Cases

Total $(n=34)$

\begin{tabular}{l}
\hline COVID-19 laboratory diagnosis \\
\hline $\begin{array}{l}\text { Real-time reverse transcription-polymerase } \\
\text { chain reaction severe acute respiratory } \\
\text { syndrome-CoV2 }\end{array}$ \\
\hline
\end{tabular}

General symptoms ( $n, \%)$

\begin{tabular}{ll}
\hline Fever & $23(68)$ \\
\hline Chill & $14(41)$ \\
\hline Dry cough & $19(56)$ \\
\hline Myalgia & $22(65)$ \\
\hline Fatigue & $18(53)$ \\
\hline Arthralgia & $5(15)$ \\
\hline Coryza & $16(47)$ \\
\hline Sore throat & $10(29)$ \\
\hline Diarrhea & $7(21)$ \\
\hline Abdominal pain & $3(9)$ \\
\hline Nausea & $3(9)$ \\
\hline Dyspnea & $13(38)$
\end{tabular}

Neurologic symptoms ( $\mathrm{n}, \%)$

\begin{tabular}{ll}
\hline Headache & $21(62)$ \\
\hline Anosmia & $17(50)$ \\
\hline Ageusia & $8(24)$ \\
\hline Delirium & $1(3)$ \\
\hline
\end{tabular}

Severity $(n, \%)$

\begin{tabular}{ll}
\hline Hospitalization & $8(24)$ \\
\hline Intensive care unit (ICU) & $4(12)$ \\
\hline Death & $1(3)$ \\
\hline
\end{tabular}

Only the frequency of ageusia was different in these groups, being more frequent in confirmed cases ( $44 \%$ vs $6 \%, p=0.02$ ).

regarding demographic and clinical features comparing confirmed and probable COVID-19 cases, except for ageusia, which was more frequent in confirmed cases $(44 \%$ vs $6 \%$, $p=0.02)$.

Considering the hospitalized patients, 6 of 8 patients exhibited ground glass opacity, and 4 of 8 patients presented 1 or more comorbidities and used immunosuppressive drugs. Among the 8 hospitalized patients, (1) 4 patients required intensive care support (severe cases); (2) 2 women without comorbidities (16 years old, EDSS 3.5, rituximab and 32 years old, EDSS 4.0, azathioprine) and 1 patient with dyslipidemia (46 years old, EDSS 7.0, azathioprine and prednisone) needed mechanical ventilation; (3) 1 patient needed ICU but no mechanical ventilation, and although patient was treated with rituximab, she was also an elderly patient ( 77 years old) exhibiting multiple comorbidities, including hypertension, diabetes, dyslipidemia, and cardiomyopathy; and (4) a 46year-old patient with EDSS 7.0 using azathioprine plus prednisone and presenting dyslipidemia died after evolving SARS, sepsis, and shock septic. Clinical characteristics of hospitalized and critical patients are summarized in eTable 1, links.lww.com/NXI/A540.

NMOSD treatment was suspended in 1 patient during the pandemic and in another during the active COVID-19. Fifteen patients (44\%) used rituximab either as a monotreatment (12; $35 \%)$ or combined with other oral immunosuppressive drugs (3; 9\%). Sixteen of 34 patients (56\%) used azathioprine as monotherapy $(10 ; 29 \%)$ or combined with prednisone (5; $15 \%)$ or rituximab $(1 ; 3 \%)$. Four of 8 hospitalized patients and 11 of 26 patients treated at home were in use of rituximab. Among the hospitalized patients, 2 patients used prednisone (with mycophenolate or azathioprine) and 1 used only azathioprine. One patient did not use any immunosuppressive drugs.

Five of 34 patients (15\%) with NMOSD presented neurologic manifestations (relapse or pseudoexacerbation) during or after SARS-CoV2 infection. A 48-year-old patient, EDSS 3.0, using rituximab, presented a new right optic neuritis 7 days after the viral infection onset, being treated with oral corticosteroids, with complete recovery (patient 1). A 25-year-old patient, EDSS 5.0, who had a previous optic neuritis, evolved with flu-like syndrome and visual acuity worsening, being treated with IV methylprednisolone with good recovery (patient 2). A 16-year-old patient, EDSS 3.5, also had optic neuritis and presented total recovery after therapy with corticosteroids (patient 3). A 22-year-old patient had myelitis, being treated with IV methylprednisolone with poor recovery (EDSS 8.5) (patient 4). A 32-year-old patient exhibited a 1-point increase in EDSS (EDSS 4.0 to 5.0), even after 50 days after being discharged from the intensive care unit (patient 5). These patients who presented neurologic manifestations requiring hospital admission are given in eTable 1 , links.lww.com/NXI/A540.

No associations were observed regarding EDSS $(\leq 4.0$ or $>4.0)$ and the duration ( $\leq 17$ or $>17$ days) of COVID-19 and its outcomes (home treatment, hospital admissions, ICU, cure, and death) in pwNMOSD. Similarly, no associations were observed between DMT type (azathioprine or rituximab) and comorbidities (without or at least 1 comorbidity) with COVID-19 outcomes (home treatment, hospital admission, ICU, cure, or death) (all $p$ values $>0.05$, data not shown).

Demographics and clinical features of COVID-19 in pwNMOSD were compared with those reported for the general Brazilian 
Table 3 Demographic and Clinical Features of COVID-19 in 18 PCR-Confirmed Patients With NMOSD Compared With Those Reported for the General Brazilian Population

\begin{tabular}{|c|c|c|c|c|}
\hline & NMOSD & $\begin{array}{l}\text { General Brazilian } \\
\text { population }\end{array}$ & $p$ Value & OR (Cl) \\
\hline $\begin{array}{l}\text { Severe acute respiratory syndrome-CoV2 } \\
\text { infection by PCR testing or serology } \\
\text { (confirmed COVID-19) }\end{array}$ & $\mathrm{n}=18$ & $\mathrm{n}=2,394,513$ & - & - \\
\hline Home treatment & $12(67 \%)$ & $2,157,661(90 \%)^{a}$ & - & - \\
\hline Hospital treatment & $6(33 \%)$ & $236,852(11 \%)$ & 0.01 & $4.6(1.6-12.0)$ \\
\hline Hospital-ICU & $4(22 \%)$ & $71,826(3 \%)^{a}$ & 0.002 & $9.2(2.6-26.8)$ \\
\hline Death & $1(6 \%)$ & $86,449(4 \%)$ & 0.62 & $1.6(0.1-8.7)$ \\
\hline \multicolumn{5}{|l|}{ Hospitalized patients } \\
\hline Men & 0 & $134,468(57 \%)$ & - & - \\
\hline Women & $6(100 \%)$ & $102,317(43 \%)$ & 0.01 & 2.0-undefined \\
\hline Age $<60$ y $(15-59)$ & $5(83 \%)$ & $101,707(43 \%)^{a}$ & 0.06 & $0.9-158.1$ \\
\hline At least 1 comorbidity & $2(33 \%)$ & $138,499(58 \%)^{a}$ & 0.25 & $0.05-2.0$ \\
\hline
\end{tabular}

Abbreviations: $\mathrm{Cl}=$ confidence interval; $\mathrm{ICU}=$ intensive care unit; $\mathrm{NMOSD}$ = neuromyelitis optica spectrum disorders; $\mathrm{OR}=$ odds ratio; $\mathrm{PCR}=$ polymerase chain reaction.

a antigo.saude.gov.br/images/pdf/2020/July/30/Boletim-epidemiologico-COVID-24.pdf and opendatasus.saude.gov.br/dataset/bd-srag-2020

population (Table 3). pwNMOSD presented with a higher frequency of hospital treatment (33\% vs $11 \%$ OR $4.6[95 \% \mathrm{CI}$ $1.6-12.0] p=0.01)$ and a higher frequency of ICU treatment $(22 \%$ vs $3 \%$ OR $9.2[95 \%$ CI 2.6-26.8] $p=0.002)$. An increased risk of death was not seen.

\section{Discussion}

To date, this study included the greatest number of probable and confirmed cases of COVID-19 among pwNMOSD. The estimated prevalence of NMOSD in Latin America is 5 of 100,000 inhabitants. ${ }^{13}$ Taking account that the Brazilian population is estimated to have $210,147,125$ inhabitants by July 25, 2020, the total number of Brazilian patients with NMOSD may be roughly estimated to 10,590 . Therefore, the coverage of the REDONE.br registry was approximately $20 \%$ of national cases, a number that can be considered a representative sample. The distribution of COVID-19 in patients with NMOSD was heterogeneous among the 5 major Brazilian regions, agreeing with the more populated areas exhibiting higher COVID-19 incidence rates in the general population. $^{14}$

The preponderance of women and African descents in pwNMOSD with COVID-19 is in accordance with the known demographic profile of the disease. ${ }^{13}$ Although male sex and older age have been associated with severity of COVID-19, ${ }^{1}$ it is possible that the female preponderance and low median age (only 1 of 34 patient was aged $>60$ years) as observed in this cohort may be responsible for the predominance of mild COVID-19 cases in pwNMOSD.
Chronic diseases such as hypertension, diabetes mellitus, heart disease, asthma, and obesity are already known to increase COVID-19 severity. ${ }^{15}$ The prevalence of known risk factors associated with severe COVID-19, such as hypertension and obesity, is also high in patients with MS and NMOSD. ${ }^{16,17}$ Although obesity, hypertension, dyslipidemia, and diabetes were observed in this series, more than half (56\%) of pwNMOSD did not present comorbidities. Although comorbidities play an important role in COVID-19 outcome, this scenario is multifaceted and cannot be resolved by this case series. $^{18}$

Besides underlying disorders, patients with NMOSD have an additional morbidity factor associated with DMT and disability related to NMOSD (EDSS). Scarce and inconclusive theoretical efforts based on the use of immunosuppressive drugs in autoimmune disorders during the pandemic or during the SARS-CoV2 infection have challenged neurologists on the decision to maintain or suspend the NMOSD treatment. ${ }^{19}$ In this series, 97\% (33/34) of patients maintained immunosuppressive drugs during the pandemic and even 97\% (32/33) during the infection. Almost half of the patients were treated with rituximab and the other half with azathioprine in mono or combined treatment.

To understand the effect of COVID-19 on pwNMOSD, we compared the NMOSD demographic and clinical features with those reported for the general Brazilian population exhibiting COVID-19, using data available at the Brazilian Ministry of Health Databank. As given in Table 3, pwNMOSD presented a higher rate of hospitalization and of ICU admission than the general population. By contrast, the frequency of death was not 
clearly higher between pwNMOSD $(n=1 ; 6 \%)$ and the general Brazilian population $(n=86,449 ; 4 \%)$. On the search for factors that could contribute to higher severity of COVID-19 in pwNMOSD, we analyzed variables such as sex, adjusted age range (15-59 years), and comorbidities between the 2 groups. A difference was observed regarding women having a higher frequency of hospital admission, which could be explained by known disease-associated incidence in women and a low number of cases included in this study. Further studies are needed to confirm this result (Table 3 ).

Because of the low prevalence of NMOSD, ${ }^{13}$ it is understandable that only case report ${ }^{8}$ and small sample size $e^{7}$ have been reported. Considering that there are expectations about the potential risk of interrupt treatment on patients with $\mathrm{NMOSD}^{20}$ and pondering the conflicting data regarding the use of anti-CD20, ${ }^{7,8,21}$ collaborative studies with sharing data are needed to clarify the effect of immunosuppressive drugs on COVID-19 severity and clinical outcome in these patients. ${ }^{22}$

Neurologic symptoms reported in this series included headache, anosmia, ageusia, and delirium, which were already described as neurologic manifestations in recently published articles. ${ }^{23} \mathrm{An}$ other important issue refers to the effect of SARS-CoV2 infection on NMOSD features. Among the patients who exhibited neurologic manifestations during COVID-19, 2 patients presented new neurologic manifestations and increased EDSS and poorly responded to methylprednisolone treatment. An additional patient exhibited a new episode of optic neuritis 7 days after COVID-19 recovery. These patients may be classified as NMOSD relapses. The other 2 patients exhibited exacerbation of their previous neurologic manifestations and presented a good response to methylprednisolone therapy. Whether these $2 \mathrm{pa}-$ tients exhibited relapse or pseudoexacerbation during COVID19 is challenging because imaging procedures were not performed. Despite the small number of patients, the coincidence between SARS-CoV2 infection and NMOSD neurologic manifestations (e.g., relapse and pseudoexacerbation) deserves further investigation to ascertain whether the virus itself or the host inflammation associated with COVID-19 may contribute to impair previous or promote new neurologic findings. ${ }^{24}$

Major methodological limitations of this study included the following: (1) the low number of tests for COVID-19 diagnosis at the time of the study and (2) the electronic communication between patients and their neurologists. Despite these limitations, this is the first data collection on patients with NMOSD in the context of the superimposed COVID-19 infection in a severely affected country.

In conclusion, most NMOSD patients with COVID-19 presented mild disease forms, particularly among women. However, pwNMOSD had much higher odds of hospitalization and ICU admission comparing with the general Brazilian population. The frequency of death was not clearly different. NMOSD disability, DMT type, and comorbidities were not associated with COVID-19 outcome. SARS-CoV2 infection

was demonstrated as a risk factor for NMOSD relapses. Collaborative studies using shared NMOSD data are needed to suitably define factors related to COVID-19 severity and neurologic manifestations.

\section{Acknowledgment}

The authors would like to thank the support of the Brazilian Academy of Neurology for the continuous incentive to strengthen the Registry of Neurological Diseases (REDONE.br). Developers of System of DataBank (administrative, technical, or material support) are Wang Sen Feng (Prontmed, São Paulo, SP), Adalberto Garcia Garces, and Lucas Frederico Arantes (Hospital das Clínicas da Faculdade de Medicina de Botucatu). Suzana Nunes Machado is deceased.

\section{Study Funding}

Brazilian Registry of Neurological Diseases of the Brazilian Academy of Neurology (REDONE.br).

\section{Disclosure}

S.L. Apostolos-Pereira, L. C. Ferreira, M. Boaventura, and F. von Glehn report no disclosures relevant to the manuscript. S.N. Machado is deceased; disclosures are not included for this author. In general, the authors from the Neuroimmunology Brazilian Study Group report no disclosures relevant to the manuscript. Go to Neurology.org/ $\mathrm{NN}$ for full disclosures.

\section{Publication History}

Received by Neurology: Neuroimmunology \& Neuroinflammation September 2, 2020. Accepted in final form June 4, 2021.

Appendix Authors

\begin{tabular}{|c|c|c|}
\hline Name & Location & Contribution \\
\hline $\begin{array}{l}\text { Samira Luisa } \\
\text { Apóstolos } \\
\text { Pereira, MD, PhD }\end{array}$ & $\begin{array}{l}\text { Hospital das Clínicas, FM- } \\
\text { USP, São Paulo, Brazil }\end{array}$ & $\begin{array}{l}\text { Design and conceptualized } \\
\text { study, analyzed the data, } \\
\text { and drafted the article for } \\
\text { intellectual content }\end{array}$ \\
\hline $\begin{array}{l}\text { Lis Campos } \\
\text { Ferreira, MD }\end{array}$ & $\begin{array}{l}\text { Universidade Federal de } \\
\text { Sergipe and Univ. } \\
\text { Tiradentes, Aracaju, } \\
\text { Brazil. }\end{array}$ & $\begin{array}{l}\text { Drafted the article for } \\
\text { intellectual content and } \\
\text { analyzed and interpreted } \\
\text { the data }\end{array}$ \\
\hline $\begin{array}{l}\text { Mateus } \\
\text { Boaventura, MD }\end{array}$ & $\begin{array}{l}\text { Hospital das Clínicas, FM- } \\
\text { USP, São Paulo, Brazil }\end{array}$ & $\begin{array}{l}\text { Drafted the article for } \\
\text { intellectual content and } \\
\text { analyzed and interpreted } \\
\text { the data }\end{array}$ \\
\hline $\begin{array}{l}\text { Nise Alessandra } \\
\text { de Carvalho } \\
\text { Sousa, MD }\end{array}$ & $\begin{array}{l}\text { Hospital Univ. Getúlio } \\
\text { Vargas, Manaus, Brazil }\end{array}$ & $\begin{array}{l}\text { Design and conceptualized } \\
\text { study, revised the article } \\
\text { for intellectual content, } \\
\text { and major role in the } \\
\text { acquisition of data }\end{array}$ \\
\hline $\begin{array}{l}\text { Gabriela Joca } \\
\text { Martins, MD }\end{array}$ & $\begin{array}{l}\text { Hospital Geral de } \\
\text { Fortaleza, Fortaleza, Brazil }\end{array}$ & $\begin{array}{l}\text { Major role in the } \\
\text { acquisition of data }\end{array}$ \\
\hline $\begin{array}{l}\text { José Arthur } \\
\text { d'Almeida, PhD }\end{array}$ & $\begin{array}{l}\text { Hospital Geral de } \\
\text { Fortaleza, Fortaleza, Brazil }\end{array}$ & $\begin{array}{l}\text { Major role in the } \\
\text { acquisition of data }\end{array}$ \\
\hline $\begin{array}{l}\text { Milena S. } \\
\text { Pitombeira, MD }\end{array}$ & $\begin{array}{l}\text { Hospital Geral de } \\
\text { Fortaleza, Fortaleza, Brazil }\end{array}$ & $\begin{array}{l}\text { Major role in the } \\
\text { acquisition of data }\end{array}$ \\
\hline
\end{tabular}


Appendix (continued)

\begin{tabular}{|c|c|c|}
\hline Name & Location & Contribution \\
\hline $\begin{array}{l}\text { Lucas Silvestre } \\
\text { Mendes, MD }\end{array}$ & $\begin{array}{l}\text { Hospital Geral de } \\
\text { Fortaleza, Fortaleza, Brazil }\end{array}$ & $\begin{array}{l}\text { Major role in the } \\
\text { acquisition of data }\end{array}$ \\
\hline $\begin{array}{l}\text { Thiago Fukuda, } \\
\text { MD }\end{array}$ & $\begin{array}{l}\text { Universidade Federal da } \\
\text { Bahia/Ebserh, Salvador, } \\
\text { Brazil }\end{array}$ & $\begin{array}{l}\text { Major role in the } \\
\text { acquisition of data }\end{array}$ \\
\hline $\begin{array}{l}\text { Hideraldo Luís } \\
\text { Souza Cabeça, } \\
\text { PhD }\end{array}$ & $\begin{array}{l}\text { Hospital Ophir Loyola, } \\
\text { Belém, Brazil }\end{array}$ & $\begin{array}{l}\text { Major role in the } \\
\text { acquisition of data }\end{array}$ \\
\hline $\begin{array}{l}\text { Luciano Chaves } \\
\text { Rocha, MD }\end{array}$ & $\begin{array}{l}\text { Hospital Ophir Loyola, } \\
\text { Belém, Brazil }\end{array}$ & $\begin{array}{l}\text { Major role in the } \\
\text { acquisition of data }\end{array}$ \\
\hline $\begin{array}{l}\text { Bianca Etelvina } \\
\text { Santos de } \\
\text { Oliveira, MD }\end{array}$ & $\begin{array}{l}\text { FUNAD, João Pessoa, } \\
\text { Brazil }\end{array}$ & $\begin{array}{l}\text { Major role in the } \\
\text { acquisition of data }\end{array}$ \\
\hline $\begin{array}{l}\text { Carla Renata } \\
\text { Aparecida Vieira } \\
\text { Stella, MD }\end{array}$ & $\begin{array}{l}\text { UNICAMP, Campinas, } \\
\text { Brazil }\end{array}$ & $\begin{array}{l}\text { Major role in the } \\
\text { acquisition of data }\end{array}$ \\
\hline $\begin{array}{l}\text { Enedina Maria } \\
\text { Lobato de } \\
\text { Oliveira, PhD }\end{array}$ & $\begin{array}{l}\text { Universidade Federal de } \\
\text { São Paulo, UNIFESP, São } \\
\text { Paulo, Brazil }\end{array}$ & $\begin{array}{l}\text { Design and conceptualized } \\
\text { study and major role in the } \\
\text { acquisition of data }\end{array}$ \\
\hline $\begin{array}{l}\text { Leizian de Souza } \\
\text { Amorim, MD }\end{array}$ & $\begin{array}{l}\text { Universidade Federal de } \\
\text { São Paulo, UNIFESP, São } \\
\text { Paulo, Brazil }\end{array}$ & $\begin{array}{l}\text { Major role in the } \\
\text { acquisition of data }\end{array}$ \\
\hline $\begin{array}{l}\text { Andréa Anacleto } \\
\text { Ferrari de } \\
\text { Castro, MD }\end{array}$ & $\begin{array}{l}\text { Universidade } \\
\text { Metropolitana de Santos, } \\
\text { Santos, Brazil }\end{array}$ & $\begin{array}{l}\text { Major role in the } \\
\text { acquisition of data }\end{array}$ \\
\hline $\begin{array}{l}\text { Antonio Pereira } \\
\text { Gomes Neto, MD }\end{array}$ & $\begin{array}{l}\text { Santa Casa, Belo } \\
\text { Horizonte, Brazil }\end{array}$ & $\begin{array}{l}\text { Major role in the } \\
\text { acquisition of data }\end{array}$ \\
\hline $\begin{array}{l}\text { Guilherme Diogo } \\
\text { Silva, MD }\end{array}$ & $\begin{array}{l}\text { Hospital das Clínicas, FM- } \\
\text { USP, São Paulo, Brazil }\end{array}$ & $\begin{array}{l}\text { Major role in the } \\
\text { acquisition of data }\end{array}$ \\
\hline $\begin{array}{l}\text { Lucas Bueno, } \\
\text { MD }\end{array}$ & $\begin{array}{l}\text { Hospital das Clínicas, FM- } \\
\text { USP, São Paulo, Brazil }\end{array}$ & $\begin{array}{l}\text { Major role in the } \\
\text { acquisition of data }\end{array}$ \\
\hline $\begin{array}{l}\text { Maria Íris de } \\
\text { Morais } \\
\text { Machado, MD }\end{array}$ & $\begin{array}{l}\text { Hospital da Restauração, } \\
\text { Recife, Brazil }\end{array}$ & $\begin{array}{l}\text { Major role in the } \\
\text { acquisition of data }\end{array}$ \\
\hline $\begin{array}{l}\text { Rafael Paternò } \\
\text { Castello Dias- } \\
\text { Carneiro, MD }\end{array}$ & $\begin{array}{l}\text { Santa Casa, São Paulo, } \\
\text { Brazil }\end{array}$ & $\begin{array}{l}\text { Major role in the } \\
\text { acquisition of data }\end{array}$ \\
\hline $\begin{array}{l}\text { Ronaldo Maciel } \\
\text { Dias, MD }\end{array}$ & $\begin{array}{l}\text { Hospital de Base do } \\
\text { Distrito Federal, Brasília, } \\
\text { Brazil }\end{array}$ & $\begin{array}{l}\text { Major role in the } \\
\text { acquisition of data }\end{array}$ \\
\hline $\begin{array}{l}\text { Alvaro Jose } \\
\text { Porto Moreira, } \\
\text { MD }\end{array}$ & $\begin{array}{l}\text { Hospital da Restauração, } \\
\text { Recife, Brazil }\end{array}$ & $\begin{array}{l}\text { Major role in the } \\
\text { acquisition of data }\end{array}$ \\
\hline $\begin{array}{l}\text { Ana Claudia } \\
\text { Piccolo, MD }\end{array}$ & $\begin{array}{l}\text { Hospital Santa Marcelina, } \\
\text { São Paulo, Brazil }\end{array}$ & $\begin{array}{l}\text { Major role in the } \\
\text { acquisition of data }\end{array}$ \\
\hline $\begin{array}{l}\text { Anderson Kuntz } \\
\text { Grzesiuk, MD }\end{array}$ & $\begin{array}{l}\text { Private Service, Cuiabá, } \\
\text { Brazil }\end{array}$ & $\begin{array}{l}\text { Major role in the } \\
\text { acquisition of data }\end{array}$ \\
\hline $\begin{array}{l}\text { Andre Muniz, } \\
\text { MD }\end{array}$ & $\begin{array}{l}\text { Clínica AMO, Salvador, } \\
\text { Brazil }\end{array}$ & $\begin{array}{l}\text { Major role in the } \\
\text { acquisition of data }\end{array}$ \\
\hline $\begin{array}{l}\text { Caio César Diniz } \\
\text { Disserol, MD }\end{array}$ & $\begin{array}{l}\text { Hospital das Clínicas, FM- } \\
\text { USP, São Paulo, Brazil }\end{array}$ & $\begin{array}{l}\text { Major role in the } \\
\text { acquisition of data }\end{array}$ \\
\hline $\begin{array}{l}\text { Claudia Cristina } \\
\text { Ferreira } \\
\text { Vasconcelos, } \\
\text { MD, PhD }\end{array}$ & $\begin{array}{l}\text { Hospital Universitário } \\
\text { Gaffree e Guinle, Rio de } \\
\text { Janeiro, Brazil }\end{array}$ & $\begin{array}{l}\text { Major role in the } \\
\text { acquisition of data }\end{array}$ \\
\hline
\end{tabular}

Appendix (continued)

\begin{tabular}{|c|c|c|}
\hline Name & Location & Contribution \\
\hline $\begin{array}{l}\text { Damacio R } \\
\text { Kaimen-Maciel, } \\
\text { PhD }\end{array}$ & $\begin{array}{l}\text { Santa Casa, Londrina, } \\
\text { Brazil }\end{array}$ & $\begin{array}{l}\text { Major role in the } \\
\text { acquisition of data }\end{array}$ \\
\hline $\begin{array}{l}\text { Denise Sisterolli } \\
\text { Diniz, PhD }\end{array}$ & $\begin{array}{l}\text { Universidade Federal de } \\
\text { Goiás, Goiânia, Brazil }\end{array}$ & $\begin{array}{l}\text { Major role in the } \\
\text { acquisition of data }\end{array}$ \\
\hline $\begin{array}{l}\text { Elizabeth R } \\
\text { Comini-Frota, } \\
\text { PhD }\end{array}$ & $\begin{array}{l}\text { Private service, Belo } \\
\text { Horizonte, Brazil }\end{array}$ & $\begin{array}{l}\text { Major role in the } \\
\text { acquisition of data }\end{array}$ \\
\hline $\begin{array}{l}\text { Fernando } \\
\text { Coronetti G Da } \\
\text { Rocha, PhD }\end{array}$ & $\begin{array}{l}\text { Faculdade de Medicina de } \\
\text { Botucatu, UNESP, } \\
\text { Botucatu, Brazil }\end{array}$ & $\begin{array}{l}\text { Major role in the } \\
\text { acquisition of data }\end{array}$ \\
\hline $\begin{array}{l}\text { Gutemberg } \\
\text { Augusto Cruz } \\
\text { dos Santos, MD }\end{array}$ & $\begin{array}{l}\text { Universidade Estácio de Sá } \\
\text { and Universidade Federal } \\
\text { Fluminenses, Rio de } \\
\text { Janeiro, Brazil }\end{array}$ & $\begin{array}{l}\text { Major role in the } \\
\text { acquisition of data }\end{array}$ \\
\hline $\begin{array}{l}\text { Yara Dadalti } \\
\text { Fragoso, PhD }\end{array}$ & $\begin{array}{l}\text { Universidade } \\
\text { Metropolitana de Santos, } \\
\text { Santos, Brazil }\end{array}$ & $\begin{array}{l}\text { Major role in the } \\
\text { acquisition of data }\end{array}$ \\
\hline $\begin{array}{l}\text { Guilherme } \\
\text { Sciascia do } \\
\text { Olival, MD }\end{array}$ & $\begin{array}{l}\text { Santa Casa and ABEM- } \\
\text { Assoc. Brasileira de } \\
\text { Esclerose Múltipla, São } \\
\text { Paulo, Brazil }\end{array}$ & $\begin{array}{l}\text { Major role in the } \\
\text { acquisition of data }\end{array}$ \\
\hline $\begin{array}{l}\text { Heloisa Helena } \\
\text { Ruocco, PhD }\end{array}$ & $\begin{array}{l}\text { Universidade Federal } \\
\text { Fluminense, Campinas, } \\
\text { Brazil }\end{array}$ & $\begin{array}{l}\text { Major role in the } \\
\text { acquisition of data }\end{array}$ \\
\hline $\begin{array}{l}\text { Heloise Helena } \\
\text { Siqueira, PhD }\end{array}$ & $\begin{array}{l}\text { Universidade Federal do } \\
\text { Mato Grosso, Cuiabá, } \\
\text { Brazil }\end{array}$ & $\begin{array}{l}\text { Major role in the } \\
\text { acquisition of data }\end{array}$ \\
\hline $\begin{array}{l}\text { H Koity Sato, } \\
\text { PhD }\end{array}$ & $\begin{array}{l}\text { Private Service, Curitiba, } \\
\text { Brazil }\end{array}$ & $\begin{array}{l}\text { Major role in the } \\
\text { acquisition of data }\end{array}$ \\
\hline $\begin{array}{l}\text { Herval Ribeiro } \\
\text { Soares Neto, } \\
\text { PhD }\end{array}$ & IAMSPE, São Paulo, Brazil & $\begin{array}{l}\text { Major role in the } \\
\text { acquisition of data }\end{array}$ \\
\hline $\begin{array}{l}\text { José Alexandre } \\
\text { Figueiredo, PhD,Jr }\end{array}$ & $\begin{array}{l}\text { Universidade Federal do } \\
\text { Mato Grosso, Cuiabá, Brazil }\end{array}$ & $\begin{array}{l}\text { Major role in the } \\
\text { acquisition of data }\end{array}$ \\
\hline $\begin{array}{l}\text { Leandro Cortoni } \\
\text { Calia, PhD }\end{array}$ & $\begin{array}{l}\text { Private Service, São Paulo, } \\
\text { Brazil }\end{array}$ & $\begin{array}{l}\text { Major role in the } \\
\text { acquisition of data }\end{array}$ \\
\hline $\begin{array}{l}\text { Mario Emilio } \\
\text { Teixeira } \\
\text { Dourado Jr, MD }\end{array}$ & $\begin{array}{l}\text { Univ. Federal R G Norte, } \\
\text { Natal, Brazil }\end{array}$ & $\begin{array}{l}\text { Major role in the } \\
\text { acquisition of data }\end{array}$ \\
\hline $\begin{array}{l}\text { Letícia Scolari, } \\
\text { MD }\end{array}$ & $\begin{array}{l}\text { Universidade Federal do } \\
\text { Mato Grosso, Cuiabá, Brazil }\end{array}$ & $\begin{array}{l}\text { Major role in the } \\
\text { acquisition of data }\end{array}$ \\
\hline $\begin{array}{l}\text { Herval Ribeiro } \\
\text { Soares Neto, } \\
\text { PhD }\end{array}$ & IAMSPE, São Paulo, Brazil & $\begin{array}{l}\text { Major role in the } \\
\text { acquisition of data }\end{array}$ \\
\hline $\begin{array}{l}\text { Luiz D Melges, } \\
\text { MD }\end{array}$ & $\begin{array}{l}\text { Faculdade de Medicina de } \\
\text { Marília, Marília, Brazil }\end{array}$ & $\begin{array}{l}\text { Major role in the } \\
\text { acquisition of data }\end{array}$ \\
\hline $\begin{array}{l}\text { Marcus Vinicius } \\
\text { Magno } \\
\text { Gonçalves, MD }\end{array}$ & $\begin{array}{l}\text { Univ. da Região de Joinville } \\
\text { (Univille), Joinville, Brazil }\end{array}$ & $\begin{array}{l}\text { Major role in the } \\
\text { acquisition of data }\end{array}$ \\
\hline $\begin{array}{l}\text { Maria Lucia } \\
\text { Vellutini } \\
\text { Pimentel, MD }\end{array}$ & $\begin{array}{l}\text { Santa Casa, Rio de Janeiro, } \\
\text { Brazil }\end{array}$ & $\begin{array}{l}\text { Major role in the } \\
\text { acquisition of data }\end{array}$ \\
\hline $\begin{array}{l}\text { Marlise de } \\
\text { Castro Ribeiro, } \\
\text { MD }\end{array}$ & $\begin{array}{l}\text { Univ. Federal Ciências da } \\
\text { Saúde de Porto Alegre, } \\
\text { Porto Alegre, Brazil }\end{array}$ & $\begin{array}{l}\text { Major role in the } \\
\text { acquisition of data }\end{array}$ \\
\hline
\end{tabular}


Appendix (continued)

\begin{tabular}{|c|c|c|}
\hline Name & Location & Contribution \\
\hline $\begin{array}{l}\text { Omar Gurrola } \\
\text { Arambula, MD }\end{array}$ & $\begin{array}{l}\text { Faculdade de Medicina de } \\
\text { Botucatu, UNESP, } \\
\text { Botucatu, Brazil }\end{array}$ & $\begin{array}{l}\text { Major role in the } \\
\text { acquisition of data }\end{array}$ \\
\hline $\begin{array}{l}\text { Paulo Diniz da } \\
\text { Gama, PhD }\end{array}$ & PUC, Sorocaba, Brazil & $\begin{array}{l}\text { Major role in the } \\
\text { acquisition of data }\end{array}$ \\
\hline $\begin{array}{l}\text { Renata Leite } \\
\text { Menon, MD }\end{array}$ & $\begin{array}{l}\text { Santa Casa, Londrina, } \\
\text { Brazil }\end{array}$ & $\begin{array}{l}\text { Major role in the } \\
\text { acquisition of data }\end{array}$ \\
\hline $\begin{array}{l}\text { Rodrigo Barbosa } \\
\text { Thomaz, MD }\end{array}$ & $\begin{array}{l}\text { Hospital Israelita Albert } \\
\text { Einstein, São Paulo, } \\
\text { Brazil }\end{array}$ & $\begin{array}{l}\text { Major role in the } \\
\text { acquisition of data }\end{array}$ \\
\hline $\begin{array}{l}\text { Rogério de Rizo } \\
\text { Morales, PhD }\end{array}$ & $\begin{array}{l}\text { Univ. Federal de } \\
\text { Uberlândia, Uberlândia, } \\
\text { Brazil }\end{array}$ & $\begin{array}{l}\text { Major role in the } \\
\text { acquisition of data }\end{array}$ \\
\hline $\begin{array}{l}\text { Silvana Sobreira, } \\
\text { MD }\end{array}$ & $\begin{array}{l}\text { Hospital Memorial São } \\
\text { José, rede D’OR, Recife, } \\
\text { Brazil }\end{array}$ & $\begin{array}{l}\text { Major role in the } \\
\text { acquisition of data }\end{array}$ \\
\hline $\begin{array}{l}\text { Suzana Nunes } \\
\text { Machado, MD (In } \\
\text { memoriam) }\end{array}$ & $\begin{array}{l}\text { Private Service, } \\
\text { Florianópolis, Brazil }\end{array}$ & $\begin{array}{l}\text { Major role in the } \\
\text { acquisition of data }\end{array}$ \\
\hline $\begin{array}{l}\text { Taysa A } \\
\text { Gonsalves Jubé } \\
\text { Ribeiro, MD }\end{array}$ & $\begin{array}{l}\text { Univ. Federal de Goiás, } \\
\text { Goiânia, Brazil }\end{array}$ & $\begin{array}{l}\text { Major role in the } \\
\text { acquisition of data }\end{array}$ \\
\hline $\begin{array}{l}\text { Valéria Coelho } \\
\text { Santa Rita } \\
\text { Pereira, MD }\end{array}$ & $\begin{array}{l}\text { Univ. Federal do Rio de } \\
\text { Janeiro, Rio de Janeiro, } \\
\text { Brazil }\end{array}$ & $\begin{array}{l}\text { Major role in the } \\
\text { acquisition of data }\end{array}$ \\
\hline $\begin{array}{l}\text { Vanessa Maia } \\
\text { Costa, MD }\end{array}$ & $\begin{array}{l}\text { Hospital Neurológico de } \\
\text { Goiânia, Goiânia, } \\
\text { Brazil }\end{array}$ & $\begin{array}{l}\text { Major role in the } \\
\text { acquisition of data }\end{array}$ \\
\hline $\begin{array}{l}\text { Adaucto } \\
\text { Wanderley da } \\
\text { Nóbrega Junior, } \\
\text { MD }\end{array}$ & $\begin{array}{l}\text { Hospital Universitário da } \\
\text { Universidade Federal de } \\
\text { Santa Catarina, } \\
\text { Florianópolis, Brazil }\end{array}$ & $\begin{array}{l}\text { Major role in the } \\
\text { acquisition of data }\end{array}$ \\
\hline $\begin{array}{l}\text { Marilia } \\
\text { Mamprim de } \\
\text { Morais Perin, } \\
\text { MD }\end{array}$ & $\begin{array}{l}\text { Pontifícia Universidade } \\
\text { Católica de Campinas, } \\
\text { Campinas, Brazil }\end{array}$ & $\begin{array}{l}\text { Major role in the } \\
\text { acquisition of data }\end{array}$ \\
\hline $\begin{array}{l}\text { Soniza Vieira } \\
\text { Alves-Leon, PhD }\end{array}$ & $\begin{array}{l}\text { Univ. Federal do Rio de } \\
\text { Janeiro, Rio de Janeiro, } \\
\text { Brazil }\end{array}$ & $\begin{array}{l}\text { Major role in the } \\
\text { acquisition of data }\end{array}$ \\
\hline $\begin{array}{l}\text { Eduardo Antonio } \\
\text { Donadi, PhD }\end{array}$ & $\begin{array}{l}\text { Faculdade de Medicina de } \\
\text { Ribeirão Preto, USP, } \\
\text { Ribeirão Preto, Brazil }\end{array}$ & $\begin{array}{l}\text { Revised the article for } \\
\text { intellectual content }\end{array}$ \\
\hline Tarso Adoni, PhD & $\begin{array}{l}\text { Hospital Sírio-Libanês, São } \\
\text { Paulo, Brazil }\end{array}$ & $\begin{array}{l}\text { Revised the article for } \\
\text { intellectual content }\end{array}$ \\
\hline $\begin{array}{l}\text { Sidney Gomes, } \\
\text { MD }\end{array}$ & $\begin{array}{l}\text { Hospital Beneficência } \\
\text { Portuguesa, São Paulo, } \\
\text { Brazil }\end{array}$ & $\begin{array}{l}\text { Major role in the } \\
\text { acquisition of data }\end{array}$ \\
\hline $\begin{array}{l}\text { Maria Lucia } \\
\text { Brito Ferreira, } \\
\text { MD }\end{array}$ & $\begin{array}{l}\text { Hospital da Restauração, } \\
\text { Recife, Brazil }\end{array}$ & $\begin{array}{l}\text { Major role in the } \\
\text { acquisition of data }\end{array}$ \\
\hline $\begin{array}{l}\text { Dagoberto } \\
\text { Callegaro, PhD }\end{array}$ & $\begin{array}{l}\text { Hospital das clínicas, FM- } \\
\text { USP, São Paulo, Brazil }\end{array}$ & $\begin{array}{l}\text { Major role in the } \\
\text { acquisition of data }\end{array}$ \\
\hline $\begin{array}{l}\text { Maria Fernanda } \\
\text { Mendes, PhD }\end{array}$ & $\begin{array}{l}\text { Santa Casa, São Paulo, } \\
\text { Brazil }\end{array}$ & $\begin{array}{l}\text { Design and conceptualized } \\
\text { study and revised the } \\
\text { article for intellectual } \\
\text { content }\end{array}$ \\
\hline
\end{tabular}

Appendix (continued)

\begin{tabular}{lll}
\hline Name & Location & Contribution \\
\hline $\begin{array}{ll}\text { Doralina G. } \\
\text { Brum MD, PhD }\end{array}$ & $\begin{array}{l}\text { Faculdade de Medicina de } \\
\text { Botucatu, UNESP, } \\
\text { Botucatu, Brazil }\end{array}$ & $\begin{array}{l}\text { Design and conceptualized } \\
\text { study, drafted the article for } \\
\text { intellectual content and } \\
\text { analyzed and interpreted } \\
\text { the data }\end{array}$ \\
\end{tabular}

Felipe von Glehn Faculty of Medicine, MD, PhD, FAAN University of Brasilia, Brasilia, Brazil

Design and conceptualized study, interpreted the data, and revised the article for intellectual content

\section{References}

1. Centers for Disease Control and Prevention. People who are at higher risk for severe illness $\mid C D C$. Atlanta, GA: Centers for Disease Control and Prevention; 2020.

2. Peeters LM, Parciak T, Walton C, et al. COVID-19 in people with multiple sclerosis: a global data sharing initiative. Mult Scler. 2020;26(10):1157-1162.

3. Sormani MP. An Italian programme for COVID-19 infection in multiple sclerosis. Lancet Neurol. 2020;19(6):481-482.

4. Louapre C, Collongues N, Stankoff B, et al. Clinical characteristics and outcomes in patients with coronavirus disease 2019 and multiple sclerosis. JAMA Neurol. 2020; 77(9):1079-1088.

5. Parrotta E, Kister I, Charvet L, et al. COVID-19 outcomes in MS: observational study of early experience from NYU Multiple Sclerosis Comprehensive Care Center. Neurol Neuroimmunol Neuroinflamm. 2020;7(5):e835.

6. Bowen JD, Brink J, Brown TR, et al. COVID-19 in MS: initial observations from the Pacific Northwest. Neurol Neuroimmunol Neuroinflamm. 2020;7(5):e783.

7. Sahraian MA, Azimi A, Navardi S, Rezaeimanesh N, Naser Moghadasi A. Evaluation of COVID-19 infection in patients with Neuromyelitis optica spectrum disorder (NMOSD): a report from Iran. Mult Scler Relat Disord. 2020;44:102245.

8. Creed MA, Ballesteros E, Jr LJG, Imitola J. Mild COVID-19 infection despite chronic $B$ cell depletion in a patient with aquaporin-4-positive neuromyelitis optica spectrum disorder. Mult Scler Relat Disord. 2020;44:102199.

9. Center for Disease Control and Prevention. Surveillance and Data Analytics-the Latest in COVID-19 Data and Surveillance; 2020.

10. Wingerchuk DM, Banwell B, Bennett JL, et al. International consensus diagnostic criteria for neuromyelitis optica spectrum disorders. Neurology. 2015;85(2):177-189.

11. Oliveira LM, Apóstolos-Pereira SL, Pitombeira MS, Bruel Torretta PH, Callegaro D, Sato DK. Persistent MOG-IgG positivity is a predictor of recurrence in MOG-IgGassociated optic neuritis, encephalitis and myelitis. Mult Scler. 2019;25:1907-1914.

12. DATASUS/SVS/MS. Painel de casos de doença pelo coronavírus 2019 (COVID-19) no Brasil pelo Ministério da Saúde [Internet]. Coronavírus//Brasil. 2020.

13. Alvarenga MP, Schimidt S, Alvarenga RP. Epidemiology of neuromyelitis optica in Latin America. Mult Scler J Exp Transl Clin. 2017;3(3):2055217317730098.

14. Ministério da Saúde. Coronavírus Brasil. 2020.

15. Richardson S, Hirsch JS, Narasimhan M, et al. Presenting characteristics, comorbidities, and outcomes among 5700 patients hospitalized with COVID-19 in the New York City area. JAMA. 2020;323(20):2052-2059.

16. Saroufim P, Zweig SA, Conway DS, Briggs FBS. Cardiovascular conditions in persons with multiple sclerosis, neuromyelitis optica and transverse myelitis. Mult Scler Relat Disord. 2018;25:21-25.

17. Ajmera MR, Boscoe A, Mauskopf J, Candrilli SD, Levy M. Evaluation of comorbidities and health care resource use among patients with highly active neuromyelitis optica. J Neurol Sci. 2018;384:96-103.

18. Carnero Contentti E, Correa J. Immunosuppression during the COVID-19 pandemic in neuromyelitis optica spectrum disorders patients: a new challenge. Mult Scler Relat Disord. 2020;41:102097.

19. Amor S, Baker D, Khoury SJ, Schmierer K, Giovanonni G. SARS-CoV-2 and multiple sclerosis: not all immune depleting DMTs are equal or bad. Ann Neurol. 2020;87(6) 794-797.

20. Abboud H, Zheng C, Kar I, Chen CK, Sau C, Serra A. Current and emerging therapeutics for neuromyelitis optica spectrum disorder: relevance to the COVID-19 pandemic. Mult Scler Relat Disord. 2020;44:102249.

21. Fan M, Qiu W, Bu B, et al. Risk of COVID-19 infection in MS and neuromyelitis optica spectrum disorders. Neurol Neuroimmunol Neuroinflamm. 2020;7(5) e787.

22. Brownlee W, Bourdette D, Broadley S, Killestein J, Ciccarelli O. Treating multiple sclerosis and neuromyelitis optica spectrum disorder during the COVID-19 pandemic. Neurology. 2020;94(22):949-952.

23. Ahmad I, Rathore FA. Neurological manifestations and complications of COVID-19: a literature review. J Clin Neurosci. 2020;77:8-12

24. Kessler RA, Mealy MA, Levy M. Early indicators of relapses vs pseudorelapses in neuromyelitis optica spectrum disorder. Neurol Neuroimmunol Neuroinflamm. 2016, 3(5):e269. 


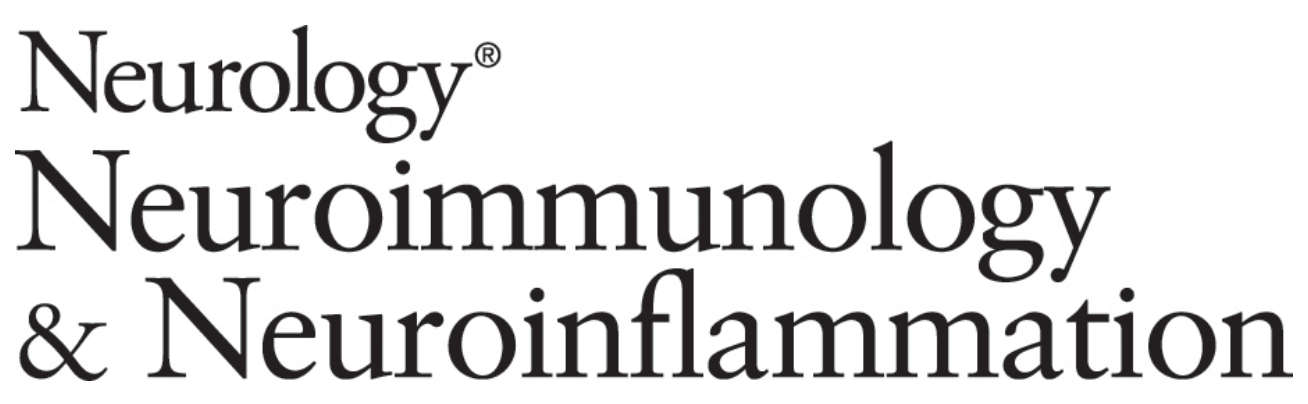

\author{
Clinical Features of COVID-19 on Patients With Neuromyelitis Optica Spectrum \\ Disorders \\ Samira Luisa Apostolos-Pereira, Lis Campos Ferreira, Mateus Boaventura, et al. \\ Neurol Neuroimmunol Neuroinflamm 2021;8; \\ DOI 10.1212/NXI.0000000000001060
}

This information is current as of August 26, 2021

Neurol Neuroimmunol Neuroinflamm is an official journal of the American Academy of Neurology.

Published since April 2014, it is an open-access, online-only, continuous publication journal. Copyright

Copyright $\odot 2021$ The Author(s). Published by Wolters Kluwer Health, Inc. on behalf of the American

Academy of Neurology.. All rights reserved. Online ISSN: 2332-7812.

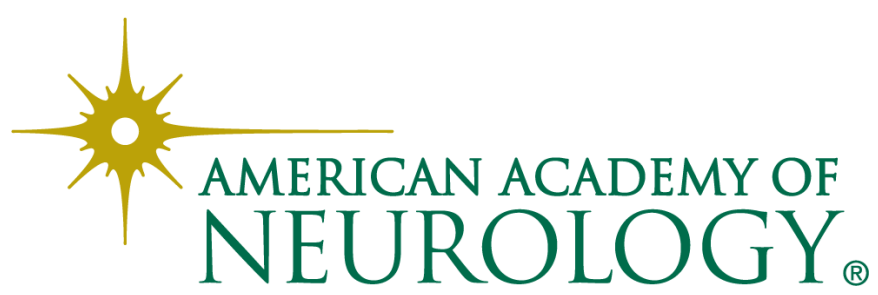




\section{Updated Information \& Services}

References

Citations

Subspecialty Collections

Permissions \& Licensing

Reprints including high resolution figures, can be found at: http://nn.neurology.org/content/8/6/e1060.full.html

This article cites 20 articles, 4 of which you can access for free at: http://nn.neurology.org/content/8/6/e1060.full.html\#\#ref-list-1

This article has been cited by 2 HighWire-hosted articles: http://nn.neurology.org/content/8/6/e1060.full.html\#\#otherarticles

This article, along with others on similar topics, appears in the following collection(s):

All epidemiology

http://nn.neurology.org//cgi/collection/all_epidemiology

Autoimmune diseases

http://nn.neurology.org//cgi/collection/autoimmune_diseases

COVID-19

http://nn.neurology.org//cgi/collection/covid_19

Devic's syndrome

http://nn.neurology.org//cgi/collection/devics_syndrome

Transverse myelitis

http://nn.neurology.org//cgi/collection/transverse_myelitis

Information about reproducing this article in parts (figures,tables) or in its entirety can be found online at:

http://nn.neurology.org/misc/about.xhtml\#permissions

Information about ordering reprints can be found online:

http://nn.neurology.org/misc/addir.xhtml\#reprintsus

Neurol Neuroimmunol Neuroinflamm is an official journal of the American Academy of Neurology.

Published since April 2014, it is an open-access, online-only, continuous publication journal. Copyright

Copyright $\odot 2021$ The Author(s). Published by Wolters Kluwer Health, Inc. on behalf of the American

Academy of Neurology.. All rights reserved. Online ISSN: 2332-7812.

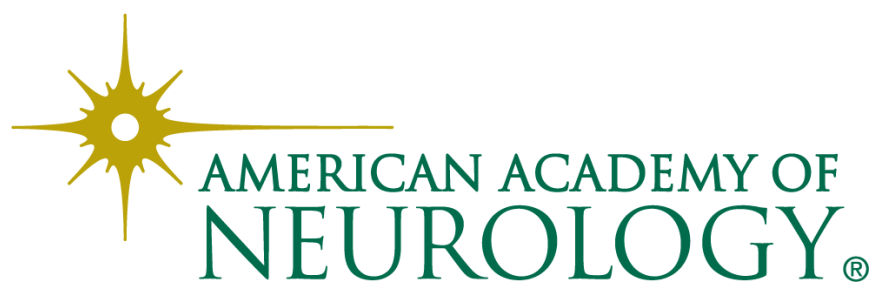

